\title{
Role of international clusters in economy of Russia and Belarus
}

\author{
Plakhin Andrey \\ Institute of management and information technologies \\ Urals state university of economics \\ Ekaterinburg, Russian Federation \\ apla@usue.ru
}

\author{
Yasheva Galina \\ Department of economic theory and marketing \\ Vitebsk State Technological University \\ Vitebsk, Republic of Belarus \\ gala-ya@list.ru
}

\begin{abstract}
The article considers the role of international cluster in increasing the innovative potential and competitiveness of the economy. The traditional cluster theory of economic development defines the cluster as a mono-branch formation localized within a certain territory. The article notes that the network nature of the economy and the development of information and computer technologies have had an impact on the development of clusters, and the formation of international industrial clusters is taking place. The purpose of the study is to substantiate the methodological aspects of increasing the competitiveness of the economies of Russia and Belarus based on international industrial clusters formation in the context of cooperation in the framework of the union state. The integration of the Republic of Belarus into the world economic community has made it possible to use the cluster approach to increase the efficiency and competitiveness of economic systems in Belarus and Russia.
\end{abstract}

Keywords - international clusters; innovative potential; the economy of Russia and Belarus; cluster approach; economic development.

\section{INTRODUCTION}

The task of increasing the competitiveness of the economy is permanent for national governments and international organizations. Its significance rises in the conditions of the socio-economic space polarization and the intensification of international competition.

One of the modern concepts of increasing the competitiveness of regional / national economies through the activation of innovation and education is the cluster concept, which is gaining increasing development in foreign countries.

The first known cluster is Chatal-Hyuk, which arose in the VIII Millennium BC and specialized in non-ferrous metallurgy and manufacture of manual tools [1]. Today the cluster is closely located and interacting companies, universities, institutions, infrastructure objects that complement each other and enhance the competitive advantages of each other [2].

Economic theory has repeatedly proven validity and credibility of the cluster approach to enhance the competitiveness of the economy. In particular, internal competition enhances the benefits of each member of the cluster and their high concentration attracts staff and customers. The cluster approach has become widespread since the 90-ies of the twentieth century and is associated with the scientific work of Michael Porter. Issues of theory and methodology of cluster development in various industries were considered in works of such Russian scholars as V. P. Vorobiev, F. S. Gubaydullina, S. R. Dreving, L. V. Ivanenko, A. E. Karlik, T. V. Mirolyubova, A. N. Nosov, I. V. Pilipenko, V. V. Pechatkin, T. V. Sakhno, K. A.Soloveichik.

In the Republic of Belarus, cluster problems were studied by D. I. Alyokhin, D. M. Krupsky, Yu. A. Rybalko, O. A. Safonova, N. G. Sinyak.

The traditional cluster theory of economic development defines the cluster as a mono-branch formation localized within a certain territory. The network nature of the economy and the development of information and computer technologies have had an impact on the formation and development of clusters: the evolution of inter-firm links from territorial production complexes to the formation of international industrial clusters is taking place. The integration of the Republic of Belarus into the world economic community, the creation of the Eurasian Economic Union (EAEU) in 2015, the development of foreign economic relations, industrial cooperation and cooperation of the international division of labor. All this has made it possible to use the cluster approach to increase the efficiency and competitiveness of economic systems in Belarus and Russia.

In Belarus and Russia, institutional conditions for clustered economic development are reflected in government policy documents as well as in the Program of Innovative Cooperation of the CIS Member States until 2020 [3-8, 12, 23].

In accordance with the adopted in 2012 Development program of the industrial complex of the Republic of Belarus up to 2020, the State program of innovative development of the Republic of Belarus for 2011-2015 (SPID) provides for the transition to the structural formation of the state industrial policy on the basis of the cluster approach. Although it is too early to assess the impact of the other new forms of spatial industry organization on the competitiveness of regions, but it should be noted that, many years (1960-1980-s), Belarus has accumulated experience in distribution of industrial enterprises in the form of industrial units (now they are called 
clusters, industrial parks, industrial zones and technology parks). And this experience indicates a high economic efficiency of the industrial hubs formation in Belarus, for which project organizations developed a unified scheme of General plans of industrial units, allowing one to save up to $40 \%$ of the cost of building the necessary industrial infrastructure.

In Russia, subjects of the cluster policy at the national level are: Ministry of economic development of the Russian Federation, the Public Council on national competitiveness, National Competitiveness Institute, and others [24].

In the Republic of Belarus, the cluster approach to modernizing the economy in the direction of innovative development is reflected in such state program documents as: the National Program for Support and Development of Exports for 2016-2020; the Concept of the State Program for Innovative Development of the Republic of Belarus for 20162020; the National Strategy for Sustainable Social and Economic Development of the Republic of Belarus for the period up to 2030. All programs envisage the creation of clusters, serving as points of growth in regional and national economies $[3,6]$.

In Russia, the elements of cluster policy are laid down in the Concept of the Long-Term Socio-Economic Development until 2030. The Program funding for a pilot innovation cluster was launched in 2012, 13 clusters received 1.3 billion rubles in 2013, 2.5 billion rubles were distributed among 25 clusters in 2014. Federal subsidies are supplemented by regional, whose size depends on the level of budget sufficiency of the region. Despite objective problems (closure of the Russian companies, a large distance from the center), gradually established previously clusters stand in the way of development. Moreover, there are new. So this year, an advanced defense cluster will be created, which will be formed on the basis of enterprises in Tambov region. Its cost will exceed 4 billion rubles [21]

In Russia the realization of the goal of clustering is supported by the state in accordance with the relevant laws and state programs: Federal law No. 488-FZ dated 31.12.2014 "On industrial policy in the Russian Federation" [7], The Resolution of the Government of the Russian Federation from 31.07.2015 No. 779 "About the industrial clusters and specialized organizations of industrial clusters" [8], The resolution of the Government of the Russian Federation 28.01.2016 № 41 "On approval of Granting Rules of subsidies from the Federal budget to the participants of industrial clusters for the reimbursement of expenses in the implementation of joint projects on the production of industrial products of the cluster in order to import substitution" [8].
In Belarus and Russia using the cluster approach as a method of overcoming the crisis phenomena in the spheres of science, technology, and sustainable development is noted in the international documents: in the Program of innovative cooperation of the countries-participants of the CIS up to 2020 [4] and in the Strategies for sustainable development in the long term.

Positive foreign experience of clustering, the processes of globalization and increased international competition, the insufficient development of the cluster mechanism of competitiveness increase of the national economy in the context of the international innovative-industrial clusters determined the goal and objectives of the study.

The purpose of the study is to substantiate the methodological aspects of increasing the competitiveness of the economies of Russia and Belarus on the basis of international innovation-industrial clusters formation in the context of cooperation in the framework of the union state.

Research objectives are:

- to assess the competitiveness of the economy of Russia and Belarus;

- to explore the international experience of clustering;

- to determine the essence of the innovationindustrial cluster, to develop a classification of clusters:

- to identify global trends in the application of the cluster approach;

- to clarify the concept and importance of the international innovation-industrial cluster;

- to determine main directions of organization of international innovation-industrial clusters in the industry of Russia and Belarus.

\section{ASSESSMENT OF THE ECONOMY OF RUSSIA AND BELARUS COMPETITIVENESS}

In the authors' opinion, the positive result of the implementation of the cluster policy in Belarus and Russia is the growth of countries in the international ranking of competitiveness according to the World Economic Forum and the Mises scientific research center "AC Strategy". According to the global competitiveness Index (GCI) for 2014-2017, Belarus has improved its position by 6 places, from the 90th place in $2014 / 15$ to the 84 th place in $2016 / 17$, Russia by 10 places, from the $53 \mathrm{~d}$ place in $2014 / 15$ to the $43 \mathrm{~d}$ place in 2016/17 (table 1) [13, 14]. 


\begin{tabular}{|c|c|c|c|c|c|c|c|c|c|c|c|c|}
\hline \multirow{3}{*}{ Country } & \multirow{2}{*}{\multicolumn{3}{|c|}{$\begin{array}{c}\text { Place by the global } \\
\text { competitiveness Index (GCI)* }\end{array}$}} & \multicolumn{9}{|c|}{ Place by sub-indexes of the GCI } \\
\hline & & & & \multicolumn{3}{|c|}{ Basic requirements $* * *$} & \multicolumn{3}{|c|}{ Performance enhancers $* * * *$} & \multicolumn{3}{|c|}{ The factors of innovativeness } \\
\hline & $\begin{array}{l}2014 / \\
2015\end{array}$ & $\begin{array}{l}2015 / \\
2016\end{array}$ & $\begin{array}{l}2016 / \\
2017\end{array}$ & $2014 /$ & $\begin{array}{l}2015 / \\
2016\end{array}$ & $\begin{array}{l}2016 / \\
2017\end{array}$ & $\begin{array}{l}2014 / \\
2015\end{array}$ & $\begin{array}{c}2015 / \\
2016\end{array}$ & $\begin{array}{ll}2016 / \\
2017\end{array}$ & $\begin{array}{l}2014 / \\
2015\end{array}$ & $\begin{array}{l}2015 / \\
2016\end{array}$ & $\begin{array}{ll}2016 / \\
2017\end{array}$ \\
\hline Switzerland & 1 & 1 & 1 & 4 & 2 & 2 & 5 & 4 & 3 & 1 & 1 & 1 \\
\hline Singapore & 2 & 2 & 2 & 1 & 1 & 1 & 2 & 2 & 2 & 11 & 11 & 12 \\
\hline USA & 3 & 3 & 3 & 33 & 30 & 27 & 1 & 1 & 1 & 5 & 4 & 2 \\
\hline Netherlands & 8 & 5 & 4 & 10 & 7 & 4 & 8 & 9 & 9 & 6 & 6 & 6 \\
\hline Germany & 5 & 4 & 5 & 11 & 8 & 10 & 9 & 10 & 7 & 4 & 3 & 3 \\
\hline Sweden & 10 & 9 & 6 & 12 & 13 & 7 & 12 & 12 & 12 & 7 & 7 & 5 \\
\hline Britain & 9 & 10 & 7 & 24 & 25 & 23 & 4 & 5 & 5 & 8 & 9 & 9 \\
\hline Japan & 6 & 6 & 8 & 25 & 24 & 22 & 7 & 8 & 10 & 2 & 2 & 4 \\
\hline Hong Kong & 7 & 7 & 9 & 3 & 3 & 3 & 3 & 3 & 4 & 23 & 23 & 23 \\
\hline Finland & 4 & 8 & 10 & 8 & 11 & 12 & 10 & 13 & 14 & 3 & 5 & 7 \\
\hline China & 28 & 28 & 28 & 28 & 28 & 30 & 30 & 32 & 30 & 33 & 34 & 29 \\
\hline Estonia & 29 & 30 & 30 & 21 & 21 & 20 & 27 & 28 & 28 & 34 & 31 & 33 \\
\hline $\begin{array}{l}\text { Czech } \\
\text { Republic }\end{array}$ & 37 & 31 & 31 & 39 & 31 & 31 & 34 & 26 & 27 & 36 & 32 & 35 \\
\hline Lithuania & 41 & 36 & 35 & 37 & 35 & 35 & 38 & 36 & 36 & 44 & 37 & 43 \\
\hline Poland & 43 & 41 & 36 & 55 & 44 & 45 & 32 & 34 & 34 & 63 & 57 & 55 \\
\hline Russia & 53 & 45 & 43 & 44 & 47 & 59 & 41 & 40 & 38 & 75 & 76 & 66 \\
\hline Latvia & 42 & 44 & 49 & 34 & 37 & 41 & 36 & 39 & 42 & 61 & 58 & 58 \\
\hline Kazakhstan & 50 & 42 & 53 & 51 & 46 & 62 & 48 & 45 & 50 & 89 & 78 & 76 \\
\hline Georgia & 69 & 66 & 59 & 48 & 51 & 46 & 79 & 77 & 69 & 118 & 118 & 113 \\
\hline Slovakia & 75 & 67 & 65 & 70 & 56 & 54 & 51 & 47 & 47 & 73 & 59 & 57 \\
\hline Ukraine & 76 & 79 & 85 & 87 & 101 & 102 & 67 & 65 & 74 & 92 & 72 & 73 \\
\hline Greece & 81 & 81 & 86 & 76 & 74 & 80 & 65 & 62 & 67 & 74 & 77 & 70 \\
\hline Moldova & 82 & 84 & 100 & 90 & 89 & 101 & 88 & 94 & 102 & 129 & 128 & 131 \\
\hline Belarus** & 90 & 87 & 84 & 104 & 100 & 92 & 93 & 91 & 90 & 97 & 94 & 91 \\
\hline
\end{tabular}

TABLE I. COUNTRIES BY THE GLOBAL COMPETITIVENESS INDEX (GCI), 2014-2017

\footnotetext{
* In the index of 2014 / 2015. - 144 countries, in 2015-2016 -140 countries, in 2016-2017 - 138 countries

** For Belarus the evaluation of the Mises Research Center "Strategy"

*** Basic requirements: institutions, infrastructure, macroeconomic stability, health, primary education.

**** Performance enhancers: higher education, the efficiency of commodity markets and the labor market, the development of the financial market, technological readiness, the size of the market.

***** Innovation factors: business experience, innovation.
}

The positive dynamics of the relatively low level of the national economies competitiveness of Russia and Belarus actualizes the problem of the further innovative development by the organization at the next stage of international clusters and, what is especially important in the authors' opinion, the development of an appropriate interaction strategy of industrial cluster formations of Belarus and Russia.

\section{INTERNATIONAL EXPERIENCE OF CLUSTERING}

World practice shows that during the last two decades, the process of cluster formation was quite active. Overall, experts estimate that to date, clustering covers about $50 \%$ of economies of the world leading countries. Leaders in clustering are: the USA (380 clusters); Italy (206 clusters); UK (168 clusters); India (106 clusters); France (96 clusters); Denmark (34 clusters); Germany (32 clusters); the Netherlands (20 clusters) (tab. 2) [2]. 
TABLE II. LEADING COUNTRIES BY THE NUMBER OF CREATED CLUSTERS IN THE WORLD

\begin{tabular}{|c|c|c|c|}
\hline Country & $\begin{array}{c}\text { Number of } \\
\text { clusters }\end{array}$ & Specialization & $\begin{array}{c}\text { Benchmarking } \\
\text { (examples of best practices) }\end{array}$ \\
\hline France & 96 & $\begin{array}{l}\text { Pharmaceuticals, } \\
\text { cosmetics, food } \\
\text { production }\end{array}$ & $\begin{array}{l}\text { Cosmetic Valley Cluster is the leader in the production of cosmetics all over the world, there are } 600 \\
\text { enterprises engaged in all the stages of work, from research to production. The cluster, which is a } \\
\text { unique source of knowledge and experience, also includes seven universities, major national research } \\
\text { institutes and } 200 \text { private and state laboratories }\end{array}$ \\
\hline India & 106 & Computer technology & $\begin{array}{l}\text { In Bangalore the Silicon plateau operates successfully. The IT industry turnover in India amounts to } 70 \\
\text { billion USD. The government of India provides major tax breaks for the companies of high technology } \\
\text { industry. So, all IT organizations may get exemption from taxes not for five years, but for ten years if } \\
\text { the company works in technopark. The tax benefits apply to any IT company regardless of the size and } \\
\text { form of ownership. }\end{array}$ \\
\hline $\begin{array}{l}\text { Great } \\
\text { Britain }\end{array}$ & 168 & $\begin{array}{l}\text { Biotechnology and } \\
\text { bioresources }\end{array}$ & $\begin{array}{l}\text { The Great Britain government has allocated } 30 \text { million USD on the establishment of the fund, which } \\
\text { will finance innovation clusters and has identified the areas around Edinburgh, Oxford and South East } \\
\text { England as the main regions of location of biotechnology firms }\end{array}$ \\
\hline Italy & 206 & $\begin{array}{l}\text { Production of } \\
\text { consumer goods, food } \\
\text { production }\end{array}$ & $\begin{array}{l}\text { Industrial clusters of Italy account for } 43 \% \text { of the number of people employed in the industry and more } \\
\text { than } 30 \% \text { of the volume of national export. The majority of clusters are single-industry ( } 90 \%) \text {, and } \\
\text { specializes on the production of consumer goods: textiles, clothing, shoes, jewelry, accessories, } \\
\text { furniture, kitchen equipment, decorative materials and sanitary equipment. One of the clearest } \\
\text { examples of industrial clusters in Italy is Sassuolo, which includes } 220 \text { companies, which employ an } \\
\text { average of } 100 \text { people. Annually, the cluster produces over } 330 \text { million square meters of ceramic tiles } \\
\text { (almost every fourth tile in the world), totally more than } 3 \text { billion EUR. The export of these products } \\
\text { brings to the country about } 1.5 \% \text { of total income from export. }\end{array}$ \\
\hline USA & 380 & Computer technology & $\begin{array}{l}\text { Silicon valley is the birthplace of the world famous companies like Intel, AMD, Oracle, Apple, Cisco, } \\
\text { Yahoo!, eBay. In the USA, more than } 50 \% \text { of enterprises work in the framework of clusters, and the } \\
\text { share of GDP produced in them is more than } 60 \% \text {. Silicon Valley is the most famous and successful of } \\
\text { them. This is the territory in California, characterized by high density of high-tech companies, } \\
\text { connected with the development and production of computers and their components. This is especially } \\
\text { true for microprocessors and software, mobile devices and biotechnology. Despite the creation of a } \\
\text { number of other innovation clusters, Silicon valley remains a leading center of this kind, getting a third } \\
\text { of all venture capital investments that are made in the USA. }\end{array}$ \\
\hline
\end{tabular}

The process of forming clusters in South-East Asia and China is active, in particular, in Singapore (petrochemicals), Japan (automotive industry) and in other countries. In China today, there are more than 60 special zones-clusters, where about 30 thousand companies employ 3.5 million people and have sales of approximately $\$ 200$ billion per year [15].

Enhancing competitiveness through cluster initiatives is becoming a basic element of development strategies of most countries. The analysis of more than 500 cluster initiatives implemented over the past 10 years in 20 countries showed that the high competitiveness of these countries is based on strong positions of separate clusters, which are drivers of competitiveness [15].

\section{THe CONCEPT AND ClassificAtion OF THE Clusters}

The concept of the "cluster(eng.)", meaning "bunch", "bunch (of grapes)", "accumulation (of stars)", in relation to industries and companies was introduced into scientific circulation by American economist M. Porter in 1990 in the framework of its concept of the national competitive advantages rhombus, which is the most famous among all the studies on national and regional competitiveness $[16,17]$.

In the world practice, a unified theory of clusters has not formed yet. There are many definitions of the cluster concept, there are not accepted classification of clusters and a common approach to the study of cluster structures. Therefore, in these conditions the continuation of conducting the system researches in the field of the conceptual apparatus formation and the main conceptual provisions of the cluster concept gets special urgency.

In order to develop the theoretical cluster foundations for the development and implementation of effective cluster strategies, taking into account the accumulated theoretical cluster database, the conceptual framework is refined.

In the authors' opinion, the cluster is the network organization of complementary, interrelated cooperative relations of enterprises and organizations (including specialized suppliers, services, as well as producers and buyers), united around one or several scientific-educational centers, which are partnerships with local institutions and agencies of the state and regional management with the aim of achieving a synergetic effect, ensuring the growth of competitiveness of enterprises, regions and national economy.

It is possible to allocate the following features of the industrial cluster: the localization and agglomeration of enterprises, organizations and public institutions, the combined horizontal and vertical relations; complementary subjects; the production of "core" goods; the presence of competition and cooperation relationships; achieving a system economic effect (profitability above the industry average level); the development of informal ties and cooperation between the subjects of the cluster, as well as partnerships between them and the regional government; common infrastructure and institutional environment; the association of companies around one or more scientific-educational centers. 
Thus, in the authors' opinion, a sign of geographical or territorial localization of the enterprises allocated by many studies at the present stage can be excluded or not to be the main, because of the intensive development of remote information and communication technologies.

Based on the stated features of the cluster, the typology of clusters is proposed, which includes the following directions of classification and types of clusters:

1. The degree of localization: local, national, international clusters. Local clusters bring together entities of the local market (city, region), national unite subjects of the country, international are united by production, cooperative, marketing ties and cooperation relations of subjects from different countries.

2. The level of cluster relations development: potential and actual clusters. Potential clusters are really existing networks (due to objective sources of localization and agglomeration), linking participants in formal relationships. They can be identified through statistical analysis (the flow of goods and services within the cluster is more than connecting it with the rest of the economy). Real clusters are unions of subjects of the clusters based on network cooperation between them and infrastructure subjects, partnership relations with local authorities, implemented within the framework of legal business community (a nonprofit organization). The main difference between potential and actual clusters is the presence of "networking", cooperation and involvement in a common goal (increasing the competitiveness of subjects of the cluster and the region).

3. Scope of the participants: wide and narrow. The differentiation of clusters on this basis is made according to the criterion of "a number of the key product manufacturers". Wide clusters include a large number of the key product manufacturers and narrow clusters include a limited number of manufacturers.

4. By the degree of the key product processing: deep, small. The criterion for classifying clusters by this feature is the number of the key product processing stages along the technological chain. In deep clusters, a large number of various products are created, in small a limited number is made.

5. The stages of the cluster life cycle: emerging cluster, the cluster in the development stage and the cluster is in the decline stage. The division of the clusters according to the life cycle stages is carried out by the dynamics of the following indicators: number of participants, productivity growth and investment in the cluster.

6. The number of subclusters in the cluster: monocluster, megacluster. The criterion of classification is the number of sector clusters included in a common cluster. Megacluster combines several different sub-clusters.

7. The level of innovation: innovation, innovativeindustrial. The innovation cluster is a geographically concentrated group of interrelated organizations, specializing in the generation and commercialization of interrelated innovations, including suppliers of equipment, components, specialized services, innovative companies-developers and manufacturers, based on the latest technological order, acting around centres of ideas and scientific knowledge (research institutes, universities, technology parks, business incubators); Characteristics of innovation cluster are the following: the technological base of companies is the latest technological order; the inclusion of cluster innovation infrastructure; the goal of clustering is to cluster generation and commercialization of innovations. The innovative industrial cluster is a cluster which members provide and carry out on a systematic and regular basis innovation activity, aimed at the development and production of innovative and high-tech (knowledge-intensive) industrial products.

\section{Global Trends in APPlying the Cluster APPROACH}

The analysis of world practice of formation and implementation of cluster strategies allows one to make a number of fundamental general conclusions.

1. Application of the cluster approach is a natural stage in the development of the economy and its ubiquity can be seen as the main feature of all developed economies.

2. The specificity of the cluster is getting a synergistic effect by its organizations, reflected in increased competitiveness of the whole system compared to individual economic entities. The cluster mechanism of increasing the competitiveness is based on the effective combination of intra-cluster cooperation in the process of production with the internal competition within the framework of the industrial cluster. It is important to emphasize the network nature of its participants interaction, because in this case the horizontal integration contributes to the formation of strictly oriented chain of distribution of new knowledge, technologies and innovations.

3. A distinctive feature of cluster is its innovative orientation. The most successful clusters form ongoing or anticipated "breakthrough" in the field of technology and production technology with the subsequent entry into new "market niches". In this regard, both economically developed and just beginning market economy forms use the "cluster approach" in the formation and regulation of their national innovation programs more actively.

4. Cluster policy implementation is based on the organization of interaction between the bodies of state power and local self-government, business and educational institutions to coordinate efforts to increase the innovativeness of production and services that promotes mutual improvement and efficiency in work.

5. Competitive clusters often have developed relationships with the similar clusters in other regions and countries. The promotion of such international linkages is becoming an important area of cluster policy, which consists in the development of 
cooperation between related clusters and in the development and implementation of development cooperation programs.

In the authors' opinion, cross-national cluster cooperation deserves special attention. Increasing globalization and informatization of society, the growing role of knowledge and need for accumulation of innovations led to the shift from the geographic location of the cluster members to their organizational and information-communication proximity in a greater degree. The formation of cluster inter-country interactions in the framework of international clusters is still poorly studied and a rather complex process because it is connected with the involvement of participants in the cluster belonging to different institutional systems.

The study of external and internal environment of clusters functioning allowed one to reveal the following trends in cluster development [18-24]

1. The internationalization of clusters, that is, the creation of new connections, restructuring the network of goods suppliers and services by business entities from abroad to extend the value chains and the creation of a new international chains of values (outsourcing, insourcing). Firms and clusters followed the path of internationalization in search of new sources of knowledge, new markets and lower labor costs.

2. The weakening of the local entities and redistribution of roles in clusters as a result of ties.

3. Creation of strategic networks.

4. Virtualization of clusters based on the development of information and computer technologies and the rapid spread of network forms of interaction.

5. The development of international relations and the creation of international clusters.

\section{THE CONCEPT AND IMPORTANCE OF INTERNATIONAL CLUSTERS}

A The clusters are subjected to internationalization at two levels:

- the micro-level or the level of firms that are members of cluster formations;

- the meso or cluster level as a whole through the implementation by coordinating entities of a cluster actions aimed at establishing cooperation at the international level.

There is sufficient empirical evidence that firms in the framework of network and cluster formations establish partnerships with foreign participants faster [25-28].

Thus, the significance of international clusters can be defined in the following:

1. The formation and development of international clusters is an effective mechanism of attracting direct foreign investments and activating external-economic integration of the countries. Clusters contribute to increasing the investment attractiveness of the region as they have a positive impact on the innovativeness of enterprises. Clusters themselves are considered by investors as points of regional growth, that is, the main incentive for foreign investors when placing their investment in a given investment area. Clusters are able to attract foreign direct investment through the development of relations, which in a certain region transform to the creation of stable framework conditions for cooperation in many fields among companies, partners, subcontractors and customers. $[29,30]$.

2. The inclusion of clusters in global chains of creation added value allows one to raise the level of national technological base significantly and to increase the pace and quality of economic growth by increasing the international competitiveness of enterprises included in the cluster, by:

- acquisition and implementation of critical technologies and the newest equipment;

- $\quad$ receiving access by cluster enterprises to modern management methods and special knowledge;

- gaining effective access by the enterprises of the cluster to highly competitive international markets.

3. The development of clusters provides optimization of the enterprises' position in the manufacturing chains, creating added value, helping to increase the degree of processing of raw materials, import substitution, increasing the localization of assembly productions and also increasing the level of non-price competitiveness of goods and services.

4. During the implementation of interstate cooperation, using the advantages of the common market, enterprises of the industry can obtain new opportunities for development. At the moment, promising areas of cooperation are: the development of integration in those sectors, where there is a possibility of import substitution and creating competitive products in the field of joint development of new technologies.

\section{MAIN DIRECTIONS OF INNOVATIVE INDUSTRIAL CLUSTERS ORGANIZATION IN THE INDUSTRY OF RUSSIA AND BELARUS}

Cluster policy is recognized as a platform for the growth of business competitiveness, ensuring a high rate of economic growth and diversification of the economies of the EAEU member countries. However, the methodical support for the implementation of the cluster policy at the sectoral level and organizational support for the creation of international clusters in the light industry of Russia and Belarus is not sufficient. In the document "Main directions of industrial cooperation within the framework of the Eurasian Economic Union", it is said that "for coordination of work on formation and 
development of the Eurasian innovation industrial clusters, the Eurasian economic Commission together with the national competent authorities prepares proposals for the adoption by the Member States of decisions on the formation of innovative industrial clusters and measures to support them" [31]. Member States of the EAEU will implement a set of measures for the support of the Eurasian innovation industrial clusters with the instruments of public procurement, fiscal, trade, customs-tariff and other policies. This actualizes the problem of developing state measures for supporting clustering.

Taking into account the importance of the clusters in the sustainable development of the national economy, the tasks for the organization of international innovative-industrial clusters are determined in the state programs of Russia and Belarus.

For the implementation of the cluster policy in Russia and Belarus, the following measures are proposed:

Economic incentives and financial support for cooperation among cluster subjects [32]:

- funding on the terms of PPP creation of the cluster infrastructure (centers for cluster development, Internet platforms, et al.);

- competitive financing of investment cluster projects;

- grants for the development of new technologies in the cluster;

- $\quad$ facilitated cooperation in education and scientific researches;

- $\quad$ state guarantees to banks for investment projects of cluster subjects;

- preferential tax treatment for small businesses within the cluster with additional benefits for innovative small organizations and for small organizations, producing import-substituting and export-oriented products;

- concessional lending to small businesses within the cluster, producing import-substituting and export-oriented production (the rate on the loan for micro and small organizations set at $50 \%$ of the refinancing rate);

- implementing the subsidization of costs: for development of small organizations in the cluster (free registration for small organizations); for product certification and quality management system for small organizations, et al.

Forms of network cooperation in enhancing innovation:

- Joint scientific researches in the field of production of the "key" good in a cluster (supplier, producer, research organization) examples: the Italian cluster of tilers, equipment for industrial waste processing (the "Catalan Leather" project);
- Joint programs of technical re-equipment (manufacturers and suppliers) - the manufacturer of the skin is funded by producers of footwear;

- Granting scientific researches, conducted by the student creative groups by the association of cluster subjects - for example, the flax association - a grant for the development of new tissues.

Examples of successfully implemented joint projects:

- "SKIF-GRID" (the development and use of supercomputing systems, software and hardware);

- "BelRosTransgen-2" (production of highlyefficient and biologically safe medicines of new generation based on human lactoferrin);

- "Cosmos-NT" (technologies of creation and application of orbital and ground facilities of the multifunctional space system);

- "Osnova" (the development of the series of integrated microcircuits and semiconductor devices) and many others;

- "Koval" (nanoconstruction of products and various materials using laser-information technologies);

- Belarusian-Russian cluster of petrochemical and refining industries.

\section{THE AlgORITHM OF STRATEGIC DEVELOPMENT AND INTERNATIONAL COOPERATION OF CLUSTERS OF BELARUS AND RUSSIA}

1.1. Development and approval of the clustered development concept at the level of Belarus and Russian Governments (done).

1.2. Studying and training of public sector representatives and business community representatives by: conducting seminars and trainings, developing training materials for entrepreneurs, and government officials; selection and training of professionals who are called to spread the ideas of clusters.

1.3. The creation of non-profit organizations associations, centers of cluster development, non-profit partnerships.

2.1. Measures of communication support for cluster initiatives and international cooperation:

- provision of premises and equipment for joint activities of the cluster members;

- creation and support of cluster infrastructure on PPP terms: cluster development centers, business incubators, business development centers;

- creation of Internet portals (Internet platform of learning, networking and collaboration; business school of distance education for the subjects of the cluster; social and business network "Cluster"); 
- $\quad$ organization of interaction among the enterprises of the cluster and the subjects of innovative infrastructure, institutions of education and science;

- organization of international business events to ensure communication between the potential participants of the cluster international cooperation (exhibitions, conferences, business meetings, et al.)

2.2. The creation of a database on the subjects of clusters in the framework of the international project office:

- $\quad$ expansion of the cluster by attracting participants from other states and establishment of crossborder clusters (for example, recommended transnational Belarusian-Russian cluster of petrochemical and refining);

- $\quad$ including in the cluster manufacturers (of the "key product", as well as ancillary and related products, for example, OJSC "Surgutneftegas" and its affiliates) located on the territory of the Russian Federation, which will contribute to the development of a competitive environment.

Taking into account the developed cluster concept, the foreign experience of clustering and the peculiarities of economic and social relations in the industry of the Republic of Belarus and Russia, the following detailed model of the organization and strategic interaction of industrial clusters of Belarus and Russia is proposed (Fig. 1).

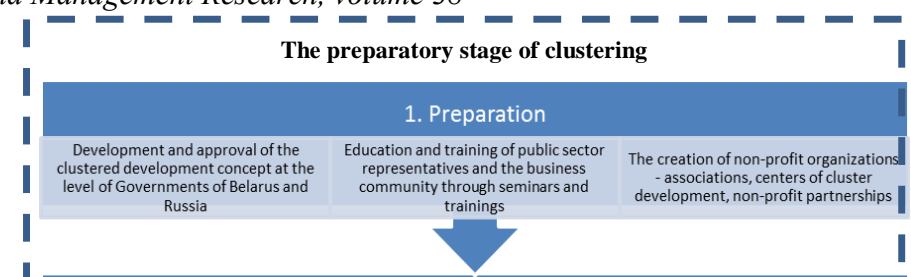

2. Development of network cooperation and public-private partnerships | Communication support of cooperation $\begin{gathered}\text { Mechanisms of network cooperation } \\ \text { and PPP in the formation of cluster }\end{gathered} \quad \begin{gathered}\text { Economic incentives and financia } \\ \text { support of cooperation }\end{gathered}$ | competitivenessfactors support of cooperation
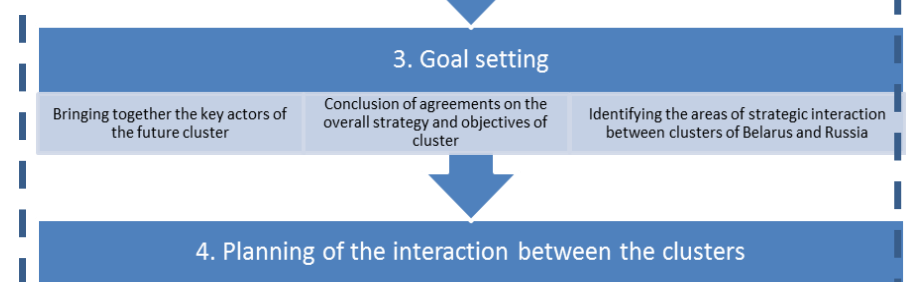

I

I The development of the project of the interaction organization between the clusters by the elected coordinators

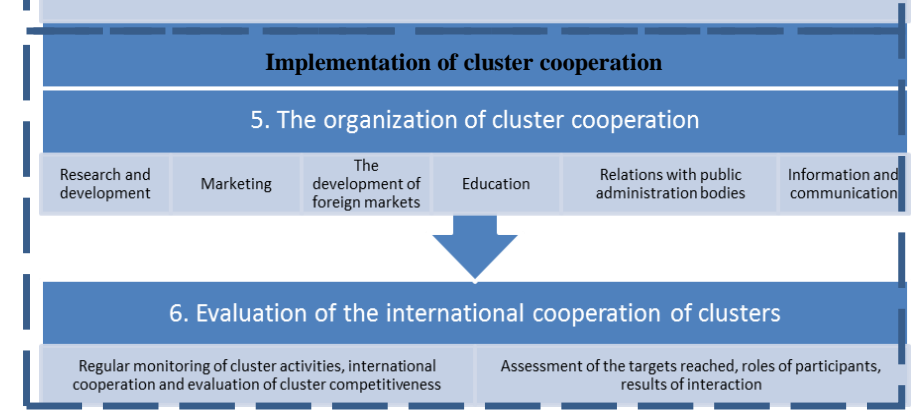

Fig. 1. The model of the process of organization and strategic cooperation of industrial clusters of Belarus and Russia ${ }^{1}$

\section{CONCLUSIONS AND PROSPECTS FOR FURTHER RESEARCH}

In terms of the need to solve the competitiveness growth problems of national economies of Russia and Belarus, it is important to pay attention to the issues connected with the advantages of economic relations in the interaction of industrial clusters. The development of methodological and organizational foundations of such interaction would enable one to implement cluster and innovation policies in these countries at a qualitatively new level.

The presented directions of the cluster approach formation will allow the subjects of management at all levels to develop and implement cluster strategies on the use of the cooperation factor in innovative development and increasing the competitiveness of the economies. A correctly built strategy of the interaction between Belarus and Russia will accelerate the diversification of these economies, will reduce its dependence on natural resources, will contribute to the development of the economic sectors and the development of previously powerful areas, which during the transition period has been given relatively little attention.

At the same time, for enhancing the competitiveness in the future, a great importance will be provided by further researches on the possibilities of strengthening the position of

\footnotetext{
${ }^{1}$ Compiled by the authors
} 
technologically related industries, including increasing the technical level of integrated cluster network industries by bringing scientific knowledge, intellectual capital and innovative activities in both countries, as well as building relationships with suppliers of materials, components and consumers of finished products.

The experience of the cluster cooperation between the Russian Federation and the Republic of Belarus in the conditions of formation of the Union state can be used in the framework of the Customs Union and the common economic space, and later - in the Eurasian Economic Union.

\section{References}

[1] Federal Law "On Industrial Policy in the Russian Federation" of December 31, 2014, No 488-FZ.

[2] The State Program of Innovative Development of the Republic of Belarus for 2011-2015, Minsk, 2011.

[3] Decree of the Government of the Russian Federation No. 779 of July 31, 2015 (Edited on September 26, 2016) "On industrial clusters and specialized organizations of industrial clusters".

[4] Decree of the Government of the Russian Federation of 28.01.2016 No. 41 (Edited on May 25, 2016) "On approval of the rules for granting subsidies to the participants of industrial clusters from the federal budget to compensate part of the costs when implementing joint projects for the production of cluster industrial products for import substitution purposes." Available Http://government.ru/media/files/7QTIRH58 taCDhnZj2AtMKj4kI5Zd0y2X.pdf Accessed 01.03.2017.

[5] Order of the Government of the Russian Federation of November 17, 2008 No 1662-r. "On the approval of the Concept of long-term socioeconomic development until 2030".

[6] "Model innovation code for CIS member states" (Adopted in St. Petersburg on November 28, 2014 by Resolution 41-23 at the 41st plenary meeting of the Interparliamentary Assembly of CIS Member States).

[7] A.E. Plakhin, E.S. Ogorodnikova, "Institutional conditions for creating clusters in the economy of Russia and the Republic of Belarus", Proceedings of the Ural State Economic University, Ekaterinburg, 2016, pp. 187-190.

[8] A.E. Plakhin, E.S. Ogorodnikova, "Factors of competitiveness of industrial park structures of cluster type. In the collection: New industrialization: the world, national, regional dimension", Materials of the international scientific-practical conference, 2016, pp. 71-76.

[9] A.Konstantynova, J.Wilson, "Comparing Cluster Policies: An Analytical Framework", Orkestra Working Paper Series in Territorial Competitiveness, No.2014-R01 (ENG), 2014. Available http://www.orkestra.deusto.es/images/ investigacion/publicaciones/papers/2014-r01wps.pdf Accessed 01.03.2017

[10] A.N. Maltsev, "Clusters in the modern world: rating of the most developed countries", 2015, Available http://ppt.ru/news/134649 Accessed 01.03.2017.

[11] D.D.Fundeanu, C.S. Badele, "The Impact of Regional Innovative Clusters on Competitiveness", Procedia - Social and Behavioral Sciences, Vol.124, pp 405-414, March 2014. Available http://www.sciencedirect.com/science/ article/pii/S1877042814020503 Accessed 01.03.2017

[12] E.A. Kostyuchenko, "Assessment of Clustering Potential of the Petrochemical Complex of the Vitebsk Region", Consumer Cooperation, No. 1 (48), 2015, pp. 80-84.

[13] E.U. Soya, "How to write about the city from the point of view of space?", Logos, No. 3, 2008, pp. 130-140.
[14] G.A.Vlasken, E.B.Lenchuk, "Cluster approach in the strategy of innovative development of foreign countries", Problems of modern economy, No 1-2, 2012, pp. 73-74.

[15] G.A.Yasheva, "Methodological basis of the cluster approach in increasing the competitiveness of enterprises", Belarusian economic journal, No 2, 2012, pp. 90-96

[16] G.A.Yasheva, "Formation of the cluster mechanism of activation of innovative activity in the Republic of Belarus", Belarusian. Economical. Journal, No. 4, 2008, pp. 75-88.

[17] G.A. Yasheva, "Substantiation of the cluster approach to increasing the efficiency of regional production", Vestnik, Vitebsk State Technological University, No 2 (23), 2012, pp. 171-181.

[18] G.A. Yasheva, "Clusters in the Belarusian Economy", Science and innovations, No. 8 (114), pp 34-36; No. 9 (115), 2012, pp. 4-20.

[19] G.A. Yasheva, "Cluster strategy of development of economies of the union states in the conditions of the Eurasian integration", Dynamics of systems, mechanisms and machines, No 5, 2014, pp. 160-163.

[20] G.A.Yasheva, V.A. Kunin, "Cluster Strategy for Innovative Development of the Economies of Russia and Belarus", Management of Economic Systems: electronic scientific journal, No. (62), 2014 UECC 2/2014, Available http: // http://uecs.ru/index Accessed 01.03.2017.

[21] J. Romanchuk, "How to make the economy of growth and development", 2017, Available http://liberty-belarus.info/ekonomikabelarusi/ mezhdunarodnye-organizatsii-v-rb/item/3669 konkurentosposobnost-2017 Accessed 01.03.2017.

[22] M. Gulati, "Improving efficiency of service provision -relevance of the cluster approach", UNIDO-NEW DELHI, 2003, Available http://www.oecd.org/daf/corporate Accessed 01.03.2017.

[23] M.E. Porter, "Competition", tr. from English. Williams Publishing House, Moscow, 2005, 608 p

[24] M.E. Porter, "The Competitive Advantage of Nations. 2nd ed", Free Press, New York, 1998, 268 p

[25] S.Luukkainen, "Industrial Cluster in the Finnish Economy", VTT Group for Technology Studies. P.O. BOX 1002, 2002, Available http://www.oecd.org/daf/corporate Accessed 01.03.2017.

[26] Cluster Observatory in the EU. The site of the EU, 2016, Available www.clusterobservatory.eu. Accessed 01.03.2017.

[27] Global Competitiveness Report 2014-2015, Available: http://www3.weforum.org/docs/WEF_GlobalCompetitivenessReport_20 14-15.p Accessed 01.03.2017

[28] Global Competitiveness Report 2016-2017. September 2016, Available http://www3.weforum.org/docs/GCR2016

2017/05FullReport/TheGlobal 2017_FINAL.pdf Accessed 01.03.2017.

[29] Interstate program of innovative cooperation of the CIS member states for the period until 2020. Adopted by the decision of the Council of Heads of Government of the CIS in St. Petersburg on 18.10.2011, 2016, Available http://www.consultant.ru/cons/cgi/online.cgi?req = doc; base $=\mathrm{INT} ; \mathrm{n}=53103$ \# 0 Accessed 01.03.2017.

[30] Measures of state support of industrial clusters. Association of cluster and technoparks. Available http://www.bronadmin.ru/ business / presentation0316.pdf Accessed 01.03.2017.

[31] On the approval of the Concept for the formation and development of innovation-industrial clusters in the Republic of Belarus and measures for its implementation: Resolution of the Council of Ministers of the Republic of Belarus. ConsultantPlus. Belarus, CJSC, ConsultantPlus, 16.01.2014, No. 27

[32] The main directions of industrial cooperation within the framework of the Eurasian Economic Union. Moscow 2015: The Eurasian Economic Commission. (Member of the Collegium (Minister) for Industry and the Agro-Industrial Complex S.Sidorsky.) Available http://www.eurasiancommission.org/ru/act/prom_i_agroprom SiteAssets/\%D0\%B1\%D1\%80\%D0\%BE\%D1\% 88\% D1\% 8E\% D1\%

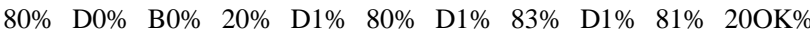
20NEW.pdf Accessed 01.03.2017. 